\title{
Umowa spółki cichej - podatkowoprawne skutki jej zawarcia i wykonywania
}

\author{
Agreement of the silent partnership - tax and legal \\ consequences of its conclusion and execution
}

Streszczenie. Instytucja spółki cichej nie jest obecnie uregulowana w żadnym akcie prawnym w polskim systemie prawnym, choć jej doniosłość w praktyce nie budzi wątpliwości. Jak każda czynność dokonywana w sferze gospodarczej i ekonomicznej zawarcie i wykonywanie umowy spółki cichej wiąże się z określonymi skutkami na gruncie prawa podatkowego. Ze względu jednak na brak ustawowej regulacji tej instytucji problematyczna jest kwestia ustalenia skutków podatkowoprawnych. Stąd szczególnej uwagi wymaga zarówno zagadnienie określenia tych skutków na gruncie podatku dochodowego, podatku od towarów i usług, podatku od czynności cywilnoprawnych oraz podatku od spadków i darowizn, jak i kwestia ponoszenia odpowiedzialności za zobowiązania podatkowe spółki cichej.

Słowa kluczowe: spółka cicha; umowa spółki cichej; podatek; podatki.

Abstract. The institution of the silent partnership is not currently regulated by any legal act in the Polish legal system, although its importance in practice is not in doubt. As every action made in the economic sphere and economic execution 
of the contract is associated with specific effects on the basis of the tax laws. However, due to the lack of statutory regulation of the institution of silent partnership problematic is the question of determining the effects of tax legislation. Therefore, special attention is needed to determine the issue of these effects on the basis of income tax, tax on goods and services, transfer tax and the tax on inheritance and donations, as well as the question of liability for the tax liabilities of the silent partnership.

Keywords: silent partnership; agreement of the silent partnership; tax; taxes.

\section{Uwagi ogólne}

W latach 90. XX w. w doktrynie i literaturze szeroko omawiana była kwestia przywrócenia regulacji ustawowej dotyczącej spółki cichej ${ }^{1}$. Postulaty de lege ferenda wysuwane w tym zakresie przez doktrynę nie zostały jednak uwzględnione przez ustawodawcę, co nie umniejsza jednak roli i znaczenia spółki cichej w życiu gospodarczym. Spółka cicha posiada istotne znaczenie w profesjonalnym (oraz transgranicznym) obrocie gospodarczym, pojawia się również w bardziej odformalizowanych stosunkach rodzinnych (spółka cicha utworzona pomiędzy małżonkami lub pomiędzy rodzicami i dziećmi). Skala rozpowszechnienia spółki cichej jest jednak trudna do zbadania, co jest wynikiem niejako jej „utajnienia”.

Jednak pomimo wieloletniego funkcjonowania w stosunkach gospodarczych zagadnienie spółki cichej wciąż zbudza wiele wątpliwości i kontrowersji. Brak jednoznaczności co do charakteru i skutków spółki cywilnej występuje na gruncie prawa zarówno cywilnego, jak i podatkowego.

Sytuacja taka doprowadziła do tego, iż na gruncie prawa podatkowego, w tym rozstrzygnięć wydawanych odnośnie spółki cichej, pojawiła się niepewność podatnika co do treści rozstrzygnięcia organu podatkowego wobec niego.

1 Por. m.in. A. Jędrzejewska, „Cywilna” spółka o charakterze wewnętrznym a „handlowa” spółka cicha, „Przegląd Prawa Handlowego” 1995, nr 5, s. 19; J. Jacyszyn, Spółka cicha jako forma prowadzenia działalności gospodarczej w Polsce, „Rejent” 1994, nr 7-8, s. 116-117 oraz później A. Koronkiewcz, Spótka cicha jako umowa sui generis, „Rejent” 2007, nr 1 (189), s. 144. 
Istotna zatem - z punktu widzenia pewności praktyki i obrotu gospodarczego oraz realizacji zasady zaufania podatnika do organów podatkowych - jest analiza skutków podatkowoprawnych zawarcia i wykonywania umowy spółki cichej, w szczególności konsekwencji właściwego zakwalifikowania umowy rzeczonej spółki na gruncie poszczególnych podatków. Powstaje jednak wątpliwość, czy określenie jednoznacznych skutków zawarcia i wykonywania umowy spółki cichej jest zasadniczo możliwe wobec braku normatywnej regulacji tej spółki oraz będącej tego następstwem naturalnej jej niedookreśloności. Niniejsze opracowanie poświęcono problematyce towarzyszącej zawieraniu i wykonywaniu umów nieuregulowanej normatywnie spółki cichej na gruncie polskiego prawa podatkowego.

\section{Istota spółki cichej}

Spółka cicha nie doczekała się uregulowania w obecnie obowiązującym Kodeksie spółek handlowych ${ }^{2} \mathrm{w}$ przeciwieństwie do sytuacji istniejącej pod rządami Kodeksu Handlowego z 1934 r. $^{3}$ do 31 grudnia 1964 r. Wspomniany Kodeks Handlowy zawierał normatywną regulację omawianej spółki, rozpoczynającą się od art. 682 i kończącą na art. 695. Regulacja ta przewidywała, że spółka cicha zawiązywana była pomiędzy wspólnikiem cichym („wspólnikiem cichym”4) a przedsiębiorcą („kupcem”5). Istota tej spółki sprowadzała się do wniesienia przez wspólnika cichego wkładu do przedsiębiorstwa kupca, które prowadził „w imieniu wła-

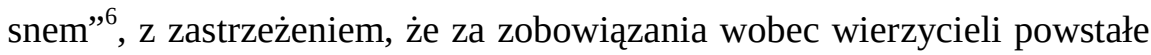
w związku z prowadzeniem tego przedsiębiorstwa wspólnik cichy nie ponosi odpowiedzialności. W zamian za wniesienie wkładu wspólnik cichy uczestniczył w zysku osiągniętym przez przedsiębiorcę. Zasadniczo

2 Ustawa z dnia 15 września 2000 r. Kodeks spółek handlowych (tekst jedn. Dz.U. z 2016 r. poz. 1578 ze zm., dalej: Kodeks spółek handlowych).

3 Rozporządzenie Prezydenta Rzeczypospolitej z dnia 27 czerwca 1934 r. Kodeks Handlowy (Dz.U. z 1934 r. nr 57 poz. 502, dalej: Kodeks Handlowy z 1934 r.).

4 Takim pojęciem posługuje się art. 682 § 1 Kodeksu Handlowego z 1934 r. Takim pojęciem posługuje się art. 682 § 1 Kodeksu Handlowego z 1934 r. Art. $682 \S 1$ Kodeksu Handlowego z 1934 r. 
wspólnik cichy uczestniczył również w stratach przedsiębiorstwa prowadzonego przez drugiego ze wspólników, przy czym jednak jedynie do wysokości umówionego wkładu, a nadto umowa spółki mogła zwolnić wspólnika cichego od udziału w stratach.

Konstrukcja spółki cichej szeroko omawiana jest jednak w literaturze i uwzględniana jest przez organy orzekające i sądy w wydawanych przez nie orzeczeniach. W literaturze wskazuje się zasadniczo na trzy podstawowe cechy stosunku prawnego, charakterystyczne dla spółki cichej, które oparte zostały na regulacji zawartej w Kodeksie Handlowym z 1934 r.:

1. wspólnik cichy uczestniczy wkładem majątkowym w przedsiębiorstwie należącym do kupca, który prowadzi je w imieniu własnym;

2. wspólnik cichy uczestniczy w zyskach osiąganych przez to przedsiębiorstwo, podczas gdy jego uczestnictwo w stratach może być ograniczone lub wyłączone, oraz

3. wspólnik cichy nie ponosi odpowiedzialności za zobowiązania przedsiębiorcy ${ }^{7}$.

Oprócz trzech powyższych cech, wynikających wprost z przepisów Kodeksu Handlowego z 1934 r. w doktrynie wskazuje się również dalsze cechy charakterystyczne dla typowej formy omawianej spółki:

4. brak jakiejkolwiek postaci wspólnego majątku obu wspólników, co oznacza, że wkład wniesiony przez wspólnika cichego scala się z majątkiem przedsiębiorstwa ${ }^{8}$;

5. dowolność formy prowadzonego przedsiębiorstwa;

6. brak ograniczeń co do rodzaju wkładu (może występować wkład zarówno pieniężny, jak i niepieniężny w każdej formie);

7. anonimowość wspólnika cichego w stosunkach zewnętrznych (nie jest ujawniany ani w rejestrach przedsiębiorców, ani w firmie przedsiębiorstwa);

7 K. Żurek, Spółka cicha. Charakter prawy. Funkcje i zalety. Wzory pism, Kraków 1999, s. 36 oraz A. Jędrzejewska, Z problematyki nietypowej spółki cichej, „Przegląd Prawa Handlowego" 1995, nr 3, s. 1.

8 A. Koch, Spótka cicha w świetle przepisów kodeksu cywilnego, „Przegląd Prawa Handlowego" 1995, nr 7, s. 2. 
8. wyłączenie wspólnika cichego od prowadzenia spraw przedsiębiorstwa, a także od jego reprezentacji ${ }^{9}$.

Ze względu na brak obowiązującej regulacji normatywnej tej spółki oraz zasadę swobody umów wynikającą z art. $353^{1}$ Kodeksu cywilnego ${ }^{10}$, zawarte przez wspólników umowy spółki cichej mogą również odchodzić od przedstawionej powyżej jej typowej formy. Nie ulega wątpliwości, iż dalsze uszczuplenie praw wspólnika cichego nie jest już możliwe, stąd jest jedynie rozbudowanie jego uprawnień: poprzez przyznanie mu uprawnienia o charakterze zobowiązaniowym i wewnętrznym wobec przedsiębiorcy do udziału w substancji majątkowej przedsiębiorstwa lub poprzez przyznanie mu prawa współdecydowania w prowadzeniu sprawy tego przedsiębiorstwa ${ }^{11}$. Jednakże nawet przy tworzeniu nietypowych form spółki cichej zasadnicze cechy charakterystyczne tej spółki nie ulegają zmianie, bowiem w dalszym ciągu realizowane są trzy podstawowe cechy określone przez Kodeks Handlowy z 1934 r. ${ }^{12}$

Niezależnie od kształtu umowy spółki cichej, obecnie w literaturze przedstawia się zgodny pogląd, iż jest ona jedynie nienazwaną umową czysto obligacyjną ${ }^{13}$. Również pod rządami Kodeksu Handlowego z 1934 r. stanowiła ona jedynie stosunek zobowiązaniowy, na co wskazywała wykładnia systemowa tego aktu prawnego - wtedy umowa spółki cichej uregulowana była w rozdziale IX działu III „Zobowiązania” księgi drugiej „Czynności handlowe”, nie zaś w księdze pierwszej regulującej działalność kupca. Już wtedy więc spółka cicha funkcjonowała nie jako forma organizacyjna czy spółka prawa handlowego, ale jako umowa dwustronnie zobowiązująca ${ }^{14}$.

\footnotetext{
G. Jędrejek, Spółka cicha, Warszawa 2008, s. 24.

Ustawa z dnia 23 kwietnia 1964 r. Kodeks cywilny (tekst jedn. Dz.U. z 2016 r. poz. 380 ze zm., dalej: Kodeks cywilny).

A. Jędrzejewska, $Z$ problematyki..., s. 1.

Tamże, s. 5.

G. Jędrejek, Spótka...., s. 13.

G. Jędrejek, Spółka..., s. 39-41.
} 


\section{Umowa spółki cichej a inne umowy w prawie polskim}

Ze względu na brak obowiązującej regulacji, względnie dużą swobodę stron umowy do kształtowania jej treści oraz płynną granicę dzielącą spółkę cichą od umowy zobowiązaniowej oraz umowy spółki ${ }^{15}$, w praktyce często powstaje wątpliwość, czy w konkretnym przypadku można mówić o umowie spółki cichej. Zakwalifikowanie jednak danej umowy jako umowy spółki cichej bądź tez umowy innego rodzaju może mieć niekiedy niebagatelne znaczenie na gruncie prawa podatkowego. Ze względu na obszerność niniejszego opracowania wskazane zostaną umowy najbliższe konstrukcji umowy spółki cichej.

\subsection{Umowa spółki cichej a umowa spółki cywilnej}

Przez umowę spółki wspólnicy zobowiązują się dążyć do osiągnięcia wspólnego celu gospodarczego przez działanie w sposób oznaczony, w szczególności przez wniesienie wkładów ${ }^{16}$, przy czym wkład wspólnika może polegać na wniesieniu do spółki własności lub innych praw albo na świadczeniu usług ${ }^{17}$. W literaturze cieszy się dużą popularnością pogląd, iż spółka cicha jest odmianą spółki cywilnej o charakterze wewnętrznym $^{18}$. Stanowisko takie jednak nie może się ostać ze względu na różnice dotyczące essentialia negotii obu umów - przede wszystkim umowa spółki cywilnej winna zawsze zawierać:

1. oznaczenie wspólników;

2. określenie wspólnego celu gospodarczego oraz

3. oznaczenie sposobu, w jaki wspólnicy zamierzają dążyć do tego celu ${ }^{19}$.

\footnotetext{
A. Koronkiewcz, Spótka cicha..., s. 143.

Art. 860 § 1 Kodeksu cywilnego.

Art. 861 § 1 Kodeksu cywilnego.

A. Jędrzejewska, Z problematyki..., s. 5.

G. Jędrejek, Spółka..., s. 42-43.
} 
Anonimowość wspólnika cichego, stanowiąca podstawową cechę spółki cichej, wyklucza możliwość realizacji pierwszego z elementów spółki cichej. Nadto zauważyć należy, iż wspólnikowi cichemu i przedsiębiorcy nie można przypisać wspólnego celu gospodarczego, a tym bardziej niemożliwe jest określenie sposobu, w jaki będą zmierzać do osiągnięcia tego celu.

Ciężko tym samym zgodzić się z częścią autorów, wskazujących, że „Umowa spółki cichej kreuje stosunek spółki cywilnej o charakterze wewnętrznym”20, wobec czego przepisy Kodeksu cywilnego dotyczącej spółki cywilnej będą miały względem spółki cichej odpowiednie zastosowanie $^{21}$.

\subsection{Umowa spółki cichej a umowy spółek handlowych}

Spośród regulacji wszystkich spółek prawa handlowego, tj. spółki jawnej, spółki partnerskiej, spółki komandytowej, spółki komandytowo-akcyjnej, spółki z ograniczoną odpowiedzialnością oraz spółki akcyjnej, najbliższa istocie spółki cichej jest spółka komandytowa. Zgodnie z brzmieniem art. 102 Kodeksu spółek handlowych spółką komandytową jest spółka osobowa mająca na celu prowadzenie przedsiębiorstwa pod własną firmą, w której wobec wierzycieli za zobowiązania spółki co najmniej jeden wspólnik odpowiada bez ograniczenia (komplementariusz), a odpowiedzialność co najmniej jednego wspólnika (komandytariusza) jest ograniczona. Podobieństwo pomiędzy obiema spółkami dostrzec można w ukształtowaniu sytuacji wspólnika cichego i komandytariusza ${ }^{22}$. Jednakże nie można mówić tu o tożsamości regulacji, bowiem pozycja wspólnika cichego kształtuje się korzystniej niż komandytariusza - komandytariusz ponosi odpowiedzialność za zobowiązania spółki do wysokości sumy komandytowej, podczas gdy wspólnik cichy wyłączony jest

\footnotetext{
A. Koch, Spółka cicha..., s. 6.

Tamże.

G. Jędrejek, Spółka..., s. 41.
} 
od takiej odpowiedzialności, a ponadto - w razie upadłości spółki - komandytariusz może otrzymać należy mu udział w zyskach dopiero po zaspokojeniu wszystkich wierzycieli, podczas gdy wspólnik cichy dysponuje wobec swojego partnera roszczeniem, co stawia jego żądania na równo $\mathrm{z}$ roszczeniami innych wierzycieli ${ }^{23}$. Ponadto $\mathrm{w}$ literaturze zwraca się również uwagę, że spółka komandytowa jest klasyczną spółką zewnętrzną, która ponadto tworzy własny majątek ${ }^{24}$.

\subsection{Umowa spółki cichej a umowa pożyczki}

Dość powszechnie w literaturze i orzecznictwie wskazuje się na tożsamość umowy spółki cichej i umowy pożyczki ${ }^{25}$. Zauważyć jednak należy, że zgodnie z art. 720 § 1 Kodeksu cywilnego istota umowy pożyczki sprowadza się do tego, że dający pożyczkę zobowiązuje się przenieść na własność biorącego określoną ilość pieniędzy albo rzeczy oznaczonych tylko co do gatunku, a biorący zobowiązuje się zwrócić tę samą ilość pieniędzy albo tę samą ilość rzeczy tego samego gatunku i tej samej jakości. Pomiędzy umowami istnieje duże podobieństwo (sposób dokapitalizowania), jednak umowa spółki cichej przewiduje odmienny sposób wynagrodzenia - w przypadku umowy spółki cichej jest to udział w zysku, co do którego jednak nie ma pewności, czy wystąpi ${ }^{26}$. Ponadto niewątpliwie istotne jest, że przedmiotem wkładu wspólnika cichego może być dowolna rzecz lub prawo majątkowe, podczas gdy umowa pożyczki ograniczona jest do środków pieniężnych lub rzeczy oznaczonych tylko co do gatun$\mathrm{ku}^{27}$. Inaczej mówiąc, umowa pożyczki odróżnia się od umowy spółki

Tamże, s. 42.

24 A. Jędrzejewska, Spótka cicha na tle innych podobnych form kapitałowego współdziałania osób, „Przegląd Prawa Handlowego” 1995, nr 4, s. 8.

25 Tak m.in. D. Niestrzębski, Umowa spółki cichej a opłata skarbowa, „Przegląd Podatkowy” 1997, nr 5, s. 13.

26 G. Jędrejek, Spótka..., s. 46.

27 Tamże, oraz K. Żurek, Spółka cicha. Charakter prawny..., Kraków 1999, s. 98-99. 
cichej „brakiem elementu uczestnictwa w rezultacie działalności pożyczkobiorcy"28.

W celu tylko zasygnalizowania obszerności omawianego w tym punkcie zagadnienia, należy wskazać, iż w literaturze umowa spółki cichej jest porównywana również z umową darowizny, umową dzierżawy, umową użyczenia, umową poręczenia, umową o świadczenie usług, umową kredytu bankowego, umową o pracę ${ }^{29}$, umową najmu, umową o dożywocie, umową o zarząd powierniczy czy umową komisu ${ }^{30}$.

Mając na uwadze powyższe, przyjąć należy, iż spółka cicha to byt odrębny od wszelkich innych umów nazwanych lub nienazwanych funkcjonujących w polskim obrocie gospodarczym. Wobec jej odrębności na gruncie prawa cywilnego wywołuje również stosowne konsekwencje prawnopodatkowe, więc zważyć należy na skutki zawarcia i wykonywania umowy spółki cichej na gruncie prawa podatkowego.

\section{Podatkowoprawne skutki zawarcia i wykonywania umowy spółki cichej}

Mimo „utajnionego” charakteru spółki cichej nie ulega wątpliwości, że strony umowy tej spółki nie mogą zataić istnienia tej spółki przed organami podatkowymi, bowiem każdy obrót kapitałem, a także określone czynności cywilnoprawne wywierają stosowne skutki na gruncie prawa podatkowego. Stąd konieczne jest rozważanie, w jaki sposób zawarcie umowy spółki cichej i jej realizacja wpływają na status podatkowoprawny stron tej umowy.

Nie ulega wątpliwości, że zawarcie umowy spółki cichej może przynieść znaczne korzyści w zakresie prawa podatkowego, jednakże obaj wspólnicy zobligowani są do bieżącego regulowania swoich zobowiązań związanych z udziałem w zysku osiąganym przez przedsiębiorstwo - choć

\footnotetext{
D. Niestrzębski, Umowa..., s. 14.

Por. G. Jędrejek, Spótka..., s. 46-50.

K. Żurek, Spółka cicha. Charakter prawny..., Kraków 1999, s. 101-105.
} 
w oparciu o odmienne zasady niż w przypadku innych spółek ${ }^{31}$. Zasadniczą kwestią jest zatem określenie konsekwencji zawarcia i wykonywania umowy spółki cichej na gruncie podatku dochodowego, zarówno od osób fizycznych, jak i od prawnych - w zależności od statusu stron umowy. Konieczne jest również określenie obowiązków podatkowych stron umowy spółki na gruncie podatku od czynności cywilnoprawnych, podatku od towarów i usług oraz podatku od spadków i darowizn. Rozważania należałoby przy tym rozpocząć od zbadania kwestii ogólnej odpowiedzialności za zobowiązania podatkowe powstałe w związku z działalnością spółki cichej.

Istotne jest ustalenie przedmiotowych skutków w sposób jednoznaczny, bowiem umożliwia to prawidłowe określenie i wypełnienie przez strony ciążących na nich zgodnie z prawem zobowiązań podatkowych.

\subsection{Odpowiedzialność za zobowiązania podatkowe spółki cichej}

W celu rozpatrzenia kwestii ewentualnej odpowiedzialności wspólników spółki cichej za zobowiązania podatkowe powstałe w związku z prowadzeniem przedsiębiorstwa przez jego właściciela, do którego wspólnik cichy wnosi wkład, należy zauważyć, iż w wyniku zawarcia umowy omawianej spółki powstaje stosunek wewnętrzny ${ }^{32}$, niemający zewnętrznego substratu w postaci majątku spółki cichej. Nie można więc mówić o zobowiązaniach podatkowych spółki cichej, lecz rozpatrywać należy odrębnie osobiste zobowiązania podatkowej jej wspólników ${ }^{33}$. Uwzględnić przy tym należy również, iż z tytułu prowadzonej działalności gospodarczej objętej spółką cichą zobowiązana będzie zasadniczo tylko jedna jej strona, tj. przedsiębiorca ${ }^{34}$. O ewentualnej odpowiedzialności wspólnika cichego można byłoby mówić w przypadku, gdy zaistnieją któreś

\footnotetext{
31 K. Żurek, Status prawnopodatkowy wspólników spółki cichej, „Prawo Spółek” 1999, nr 11, s. 23.

Tamże.

Tamże

Tamże.
} 
z okoliczności wskazanych w Dziale III rozdziale 15 Ordynacji podatkowej $^{35}$. Po analizie zaś art. 107-119 Ordynacji podatkowej wysunąć można wniosek, że odpowiedzialność solidarna wspólnika cichego za zobowiązania powstałe w wyniku działalności przedsiębiorstwa w przypadku typowej spółki cichej aktualizowałaby się w zasadzie jedynie w czterech przypadkach:

1. gdyby wspólnik cichy równocześnie był członkiem rodziny podatnika (przedsiębiorcy) prowadzącego działalność gospodarczą oraz stale współdziałał z podatnikiem w jej wykonywaniu, osiągając korzyści z prowadzonej przez niego działalności (art. 111 § 1 Ordynacji podatkowej);

2. gdyby wspólnik cichy, za zgodą przedsiębiorcy, w celu zatajenia prowadzenia działalności gospodarczej lub rzeczywistych rozmiarów tej działalności, posługiwał się lub posługiwał się imieniem i nazwiskiem, nazwą lub firmą tego przedsiębiorcy (art. 113 Ordynacji podatkowej);

3. gdyby wspólnik cichy był właścicielem, samoistnym posiadaczem lub użytkownikiem wieczystym rzeczy lub prawa majątkowego i pozostawał z przedsiębiorcą użytkującym daną rzecz lub prawo majątkowe w związku o charakterze rodzinnym, kapitałowym lub majątkowym w rozumieniu przepisów o podatku dochodowym albo wynikające ze stosunku pracy, a ponadto dana rzecz lub prawo były związane z działalnością gospodarczą lub służyły do jej prowadzenia (art. 114 Ordynacji podatkowej);

4. gdyby wspólnik cichy był gwarantem lub poręczycielem przedsiębiorcy w zakresie istniejącego już zobowiązania podatkowego (art. 117a Ordynacji podatkowej).

Wskazać przy tym należy, iż przyjęcie rozważanej w poprzednim punkcie koncepcji, że spółka cicha jest swoistą odmianą spółki cywilnej, diametralnie zmienia kwestię odpowiedzialności za zobowiązania spółki cichej. W takiej sytuacji zastosowanie znajdowałby art. 115 § 1 Ordynacji podatkowej, na mocy którego wspólnik spółki odpowiada całym swoim

35 Ustawa z dnia 29 sierpnia 1997 r. Ordynacja podatkowa (tekst jedn. Dz.U. z 2015 r. poz. 613 ze zm., dalej: Ordynacja podatkowa). 
majątkiem solidarnie ze spółką i z pozostałymi wspólnikami za zaległości podatkowe spółki. Odpowiedzialność wspólnika cichego nie byłaby zatem uzależniona od żadnych dalszych warunków, lecz stanowiłby o niej sam jego status wspólnika tej spółki.

\subsection{Skutki zawarcia i wykonywania umowy spółki cichej na gruncie podatku dochodowego od osób fizycznych oraz podatku dochodowego od osób prawnych}

Wspólnicy spółki cichej bez wątpienia w zakresie osiąganych ze wspólnego przedsięwzięcia zysków podlegać będą regulacjom odpowiednio ustawy o podatku dochodowym od osób fizycznych ${ }^{36}$ - w przypadku gdy przedsiębiorca lub wspólnik cichy są podmiotami podlegającymi regulacjom tej ustawy - oraz ustawy o podatku dochodowym od osób prawnych $^{37}$ - gdy przedsiębiorca lub wspólnik cichy jest osobą prawną lub spółką kapitałową w organizacji.

\subsubsection{Podstawa i sposób opodatkowania}

Nie budzi zastrzeżeń, że przedsiębiorca będzie zobowiązany zapłacić podatek dochodowy od dochodu, jaki przyniesienie jego przedsiębiorstwo, natomiast wobec wspólnika cichego zobowiązanie podatkowe z tytułu udziału w spółce i jego wysokość będą uzależnione od tego, czy i w jakiej wysokości zostanie mu wypłacony zysk przez przedsiębiorcę $e^{38}$.

Niewątpliwą zaletą spółki cichej jako umowy o charakterze obligacyjnym jest możliwość wykluczenia podwójnego opodatkowania podat-

36 Ustawa z dnia 26 lipca $1991 \mathrm{r}$. o podatku dochodowym od osób fizycznych (tekst jedn. Dz.U. z 2016 r. poz. 2032 ze zm.), dalej jako ustawa o podatku dochodowym od osób fizycznych.

37 Ustawa z dnia 15 lutego 1992 r. o podatku dochodowym od osób prawnych (tekst jedn. Dz.U. z 2016 r. poz. 1888 ze zm., dalej: ustawa o podatku dochodowym od osób prawnych).

38 K. Żurek, Status prawnopodatkowy wspólników..., s. 23-24. 
kiem dochodowym osiągniętego przez przedsiębiorstwo zysku, bowiem przedsiębiorca powinien kwoty wypłacone wspólnikowi cichemu jako udział w zysku zaliczyć do kosztów prowadzonej działalności gospodarczej (tak jak ma to miejsce w przypadku m.in. zapłaty skapitalizowanych odsetek od pożyczki czy kredytu $\left.{ }^{39}\right)^{40}$. Zatem podatek dochodowy od zysku jest odprowadzany tylko jeden raz - przez każdego ze wspólników stosownie do ich udziału.

Przyjęcie, iż spółka cicha jest spółką nieposiadającą osobowości prawnej, będzie skutkowało zastosowaniem wobec przychodów z udziału w tej spółce dyspozycji art. 8 ust. 1 ustawy o podatku dochodowym od osób fizycznych, który przewiduje, że przychody z udziału w spółce niebędącej osobą prawną, ze wspólnej własności, wspólnego przedsięwzięcia, wspólnego posiadania lub wspólnego użytkowania rzeczy lub praw majątkowych u każdego podatnika określa się proporcjonalnie do jego prawa do udziału w zysku (udziału) oraz co do zasady łączy się z pozostałymi przychodami ze źródeł, z których dochód podlega opodatkowaniu według stosownej skali podatkowej. Służyć to może głównie uproszczeniu rozliczeń podatkowych pomiędzy wspólnikami ${ }^{41}$.

Fakt, że zysk przedsiębiorcy będzie podlegał opodatkowaniu podatkiem dochodowym jako pochodzący z prowadzonej przez niego działalności gospodarczej, nie budzi żadnych zastrzeżeń. Odnosząc się do opodatkowania udziału w zysku otrzymywanego przez wspólnika cichego, należy rozpatrzyć to zagadnienie w trzech aspektach w zależności od tego, do której z grup wspólników cichych zalicza się podmiot: przedsiębiorca w formie osoby prawnej, osoba fizyczna prowadząca działalność gospodarczą czy osoba fizyczna nieprowadząca działalności gospodarczej ${ }^{42}$. Gdy wspólnik cichy jest podmiotem podlegającym opodatkowaniu na podstawie ustawy o podatku dochodowym od osób prawnych, to zagadnienie opodatkowania jego udziału w zysku przedsiębiorstwa objętego

39 Art. 23 ust. 1 pkt 8 lit. a ustawy o podatku dochodowym od osób fizycznych oraz art. 16 ust. 1 pkt 10 lit. a ustawy o podatku dochodowym od osób prawnych.

$40 \quad$ K. Żurek, Status prawnopodatkowy wspólników..., s. 24.

41 Tamże.

42 G. Jędrejek, Spółka..., s. 133. 
spółką cichą w zasadzie nie budzi żadnych kontrowersji, bowiem dochody z tytułu udziału w spółce cichej łączą się z dochodami z innych źródeł i podlegają łącznemu opodatkowaniu stawką w wysokości 19\%. W przypadku natomiast, gdy wspólnik cichy jest osobą fizyczną, problematyczne staje się zakwalifikowanie zysku z tytułu udziału w spółce cichej do konkretnego źródła przychodów. W literaturze wskazuje się trzy możliwości takiej kwalifikacji:

1. przychody z pozarolniczej działalności gospodarczej (art. 10 ust. 1 pkt 3 ustawy o podatku dochodowym od osób fizycznych);

2. przychody z kapitałów pieniężnych (art. 10 ust. 1 pkt 7 ustawy o podatku dochodowym od osób fizycznych) oraz

3. przychody z innych źródeł (art. 10 ust. 1 pkt 9 ustawy o podatku dochodowym od osób fizycznych).

Pierwsza z prezentowanych możliwości opiera się na założeniu, że wspólnikowi cichemu z tytułu uczestnictwa w spółce cichej przysługują nie „prawa”, ale wierzytelność, w tym przede wszystkim prawo do pobierania zysku. Tytułem prawnym uzyskania korzyści majątkowej przez cichego wspólnika nie jest posiadany udział w kapitale przedsiębiorcy, lecz umowa cywilnoprawna ${ }^{43}$. W sytuacji, gdy wspólnikiem spółki cichej jest osoba fizyczna prowadząca działalność gospodarczą, a jej wkład do spółki związany jest z prowadzoną przez tę osobę działalnością gospodarczą, uznać należy, iż przychody wspólnika cichego z udziału w zyskach przedsiębiorcy kwalifikowane są do źródła, jakim jest pozarolnicza działalność gospodarcza ${ }^{44}$.

Drugi pogląd wywodzi się z założenia, że umowa spółki cichej, gdy przedmiotem wkładu wspólnika cichego są środki pieniężne, wykazuje największe podobieństwo do umowy pożyczki ${ }^{45}$. Stąd zysk osiągany z tytułu uczestnictwa w spółce cichej powinien być kwalifikowany jako przychód z kapitału pieniężnego, za który uważa się m.in. odsetki od pożyczek ${ }^{46}$.

43 Interpretacja indywidualna Dyrektora Izby Skarbowej w Bydgoszczy z dnia 3 listopada 2011 r., ITPB1/415-846/11/MR.

44 Tamże.

45 J. Przekopiak, Opodatkowanie przychodów wspólnika cichego uzyskanych z uczestnictwa w spółce cichej, „Prawo Spółek” 1997, nr 4, s. 59.

46 Art. 17 ust. 1 pkt 1 ustawy o podatku dochodowym od osób fizycznych. 
Ostatnie zaś stanowisko, kwalifikujące przychody wspólnika cichego jako przychody z innych źródeł, opiera się na założeniu, że umowa spółki cichej, w której wspólnik w zamian za wkład pieniężny zapewnia sobie udział w zyskach z inwestycji, nie jest tym samym co udzielenie pożyczki. Wspólnik cichy nie otrzyma więc opodatkowanych u źródła odsetek, ale przychody z innych źródeł - proporcjonalnie do swojego udziału w zysku z przedsięwzięcia ${ }^{47}$.

Ponadto wskazać należy, iż bardzo słusznie Wojewódzki Sąd Administracyjny we Wrocławiu wskazał, że „,[u]dział w zysku osiągnięty przez wspólnika cichego nie może być zakwalifikowany jako przychód z tytułu udziału w zyskach osób prawnych (art. 17 ust. 1 pkt 4 u.p.d.o.f.), skoro spółka cicha nie posiada osobowości prawnej, jak również jako przychód z pozarolniczej działalności gospodarczej (art. 10 ust. 1 pkt 3 u.p.d.o.f.). Zgodnie bowiem z art. 5a pkt 6 pozarolnicza działalność gospodarcza oznacza działalność zarobkową (...) prowadzoną we własnym imieniu bez względu na jej rezultat, w sposób zorganizowany i ciągły, z której uzyskane przychody nie są zaliczane do innych przychodów ze źródeł wymienionych w art. 10 ust. 1 pkt 1, 2 i 4-9. Natomiast wspólnik cichy nie prowadzi działalności gospodarczej we własnym imieniu" ${ }^{48}$. Takie ujęcie w pełni uzasadnione jest essentialia negotii spółki cichej.

\subsubsection{Amortyzacja przedmiotu wkładu do spółki cichej}

Odnosząc się również do instytucji podatku dochodowego, jaką jest amortyzacja, należy zauważyć, iż przedmiot wniesionego przez wspólnika cichego wkładu ma niemałe znaczenie dla możliwości dokonywania przez niego stosownych odpisów amortyzacyjnych zgodnie z regulacją art. 22a22o ustawy o podatku dochodowym od osób fizycznych lub art. 16a-16m ustawy o podatku dochodowym od osób prawnych.

47 Wyrok WSA we Wrocławiu z dnia 22 kwietnia 2015 r., I SA/Wr 213/15, CBOSA.
48 Tamże. 
Zgodnie z przywołanymi powyżej przepisami, amortyzacji podlegają co do zasady stanowiące własność lub współwłasność podatnika, nabyte lub wytworzone we własnym zakresie, kompletne i zdatne do użytku w dniu przyjęcia do używania:

1. budowle, budynki oraz lokale będące odrębną własnością,

2. maszyny, urządzenia i środki transportu oraz

3. inne przedmioty

o przewidywanym okresie używania dłuższym niż rok, wykorzystywane przez podatnika na potrzeby związane z prowadzoną przez niego działalnością gospodarczą albo oddane do używania na podstawie umowy najmu, dzierżawy lub leasingu, o wartości co najmniej 3500 zł. Amortyzacji podlegają również wartości niematerialne i prawne o przewidywanym okresie używania dłuższym niż rok, wykorzystywane przez podatnika na potrzeby związane z prowadzoną przez niego działalnością gospodarczą albo oddane przez niego do używania na podstawie umowy licencyjnej (sublicencji), umowy najmu, dzierżawy lub leasingu, również o wartości co najmniej 3500 zł.

Wniesienie do spółki cichej wkładu w postaci prawa do używania ww. składników majątku na podstawie umowy najmu, dzierżawy lub leasingu względnie umowy licencyjnej (sublicencji) umożliwi wspólnikowi cichemu dokonywanie odpisów amortyzacyjnych, które nie pozostają bez wpływu na jego sytuację podatkowoprawną.

\subsection{Skutki zawarcia i wykonywania umowy spółki cichej na gruncie podatku od czynności cywilnoprawnych}

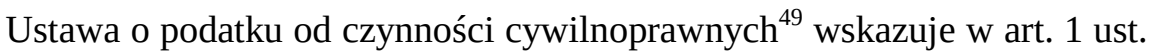
1 katalog zamknięty czynności cywilnoprawnych podlegających temu podatkowi, a mianowicie:

49 Ustawa z dnia 9 września 2000 r. o podatku od czynności cywilnoprawnych (tekst jedn. Dz.U. z 2016 r. poz. 223 ze zm., dalej: ustawa o podatku od czynności cywilnoprawnych). 
1. umowy sprzedaży oraz zamiany rzeczy i praw majątkowych,

2. umowy pożyczki pieniędzy lub rzeczy oznaczonych tylko co do gatunku,

3. umowy darowizny - w części dotyczącej przejęcia przez obdarowanego długów i ciężarów albo zobowiązań darczyńcy,

4. umowy dożywocia,

5. umowy o dział spadku oraz umowy o zniesienie współwłasności w części dotyczącej spłat lub dopłat,

6. ustanowienie hipoteki,

7. ustanowienie odpłatnego użytkowania, w tym nieprawidłowego, oraz odpłatnej służebności,

8. umowy depozytu nieprawidłowego,

9. umowy spółki,

przy czym podatkowi podlegają również zmiany powyższych umów, jeżeli powodują one podwyższenie podstawy opodatkowania podatkiem od czynności cywilnoprawnych, orzeczenia sądów, w tym również polubownych, oraz ugody, jeżeli wywołują one takie same skutki prawne, jak powyższe czynności cywilnoprawne.

Dodatkowo w art. 1a pkt 1 i 2 ustawy o podatku od spadków i darowizn ustawodawca wskazał, że określenie spółka osobowa oznacza spółkę: cywilną, jawną, partnerską, komandytową lub komandytowo-akcyjną, zaś spółka kapitałowa - spółkę: z ograniczoną odpowiedzialnością, akcyjną lub europejską.

W katalogu czynności cywilnoprawnych polegających podatkowi od czynności cywilnoprawnych brak jest wskazania umowy spółki cichej, co nakazuje przyjąć, iż zawarcie umowy spółki cichej nie wywiera skutków na gruncie tego podatku ${ }^{50}$.

Jednakże zarówno w literaturze ${ }^{51}$, jak i w orzecznictwie prezentowany jest w tym zakresie niekiedy odmienny pogląd. Dyrektor Izby Skarbowej w Katowicach w interpretacji indywidualnej z dnia 3 lutego 2009 r. ${ }^{52}$

50 Tak m.in. Dyrektor Izby Skarbowej w Warszawie w interpretacji indywidualnej z dnia 8 kwietnia 2010 r., IPPB2/436-11/10-4/MZ oraz G. Jędrejek, Spółka..., s. 132.

51 Por. D. Niestrzębski, Umowa..., s. 13-14.

52 IBPBII/1/436-14/08/MZ. 
wskazał, że pożyczka oraz wniesienie wkładu pieniężnego do spółki cichej podlega opodatkowaniu podatkiem od czynności cywilnoprawnych. Pogląd ten uzasadnił, wskazując, iż umowa spółki jest na gruncie prawa polskiego umową nienazwaną, w związku z czym dopuszczalne jest wobec niej stosowanie przepisów o umowach nazwanych, wprost lub przez analogię, w zależności od celu umowy nienazwanej i podobieństwa tego celu do umowy nazwanej. W efekcie Dyrektor Izby Skarbowej w Katowicach potraktował wniesienie wkładu przez wspólnika cichego jako udzielenie pożyczki lub jeżeli zostaną spełnione przesłanki określone w art. 860 Kodeksu cywilnego jako umowę spółki cywilnej. W zależności zatem, której z tych umów bliższe są postanowienia umowy spółki cichej, umowa ta podlegać będzie opodatkowaniu podatkiem od czynności cywilnoprawnych jako umowa pożyczki lub jako umowa spółki cywilnej.

Z poglądem tym jednak trudno się zgodzić ze względu choćby na zakaz stosowania wykładni rozszerzającej obowiązujący w prawie podatkowym.

\subsection{Skutki zawarcia i wykonywania umowy spółki cichej na gruncie podatku od spadków i darowizn}

W literaturze dostrzega się również możliwość, aby stosunki pomiędzy wspólnikiem cichym a przedsiębiorcą wywoływały skutki również na gruncie podatku od spadków i darowizn. Jako przykład wskazywane jest dokonanie darowizny przez przedsiębiorcę polegającej na oddaniu wspólnikowi cichemu wkładu w przedsiębiorstwie jego partnera w postaci konkretnego składnika majątku lub praw majątkowych, np. prawa do udziału w zysku przedsiębiorstwa ${ }^{53}$. Taka czynność będzie podlegała opodatkowaniu na podstawie art. 1 ust. 1 pkt 2 ustawy o podatku od spadków i darowizn ${ }^{54}$, zaś obowiązek podatkowy spoczywać będzie na nabywcy, tj. wspólniku cichym ${ }^{55}$.

53 K. Żurek, Status prawnopodatkowy wspólników..., s. 26.

54 Ustawa z dnia 28 lipca 1983 r. o podatku od spadków i darowizn (tekst jedn. Dz.U. z 2016 r. poz. 205 ze zm., dalej: ustawa o podatku od spadków i darowizn).

55 Art. 5 ustawy o podatku od spadków i darowizn. 


\subsection{Skutki zawarcia i wykonywania umowy spółki cichej na gruncie podatku od towarów i usług}

W literaturze zgodnie wskazuje się, że zawarcie i wykonywanie umowy spółki cichej pozostaje bez wpływu na zobowiązania podatkowe w zakresie podatku od towarów i usług ${ }^{56}$. Uwzględniając, że spółka cicha nie posiada żadnego zewnętrznego substratu, nie jest ona objęta zakresem podmiotowym ustawy o podatku od towarów i usług ${ }^{57}$. Zgodnie bowiem z art. 15 ust. 1 ustawy o podatku od towarów i usług podatnikami tego podatku są osoby prawne, jednostki organizacyjne niemające osobowości prawnej oraz osoby fizyczne, wykonujące samodzielnie działalność gospodarczą, bez względu na cel lub rezultat takiej działalności.

Oznacza to, że rozpatrywać należy osobno kwestię podlegania ustawie o podatku od towarów i usług wobec każdego ze wspólników. Biorąc pod uwagę typową postać spółki cichej jako stosunku obligacyjnego, podatnikiem podatku od towarów i usług będzie jedynie przedsiębiorca w zakresie prowadzonej przez niego działalności gospodarczej ${ }^{58}$. Wspólnik cichy natomiast nie będzie dokonywał czynności objętych dyspozycją ustawy o podatku od towarów i usług.

Powyższy pogląd znajduje również potwierdzenie w orzecznictwie. Wojewódzki Sąd Administracyjny w Gorzowie Wielkopolskim ${ }^{59}$ wskazał, iż to na osobie faktycznie dokonującej czynności podlegających opodatkowaniu podatkiem od towarów (prowadzącej we własnym imieniu działalność gospodarczą) i usług ciąży z tego tytułu stosowne zobowiązanie podatkowe.

Inny natomiast skutek wywoływałoby uznanie spółki cichej za spółkę cywilną o charakterze wewnętrznym. Takie określenie statusu spółki cichej skutkowałoby uznaniem jej za podatnika podatku od towarów

\footnotetext{
K. Żurek, Status prawnopodatkowy wspólników..., s. 25.

57 Ustawa z dnia 11 marca 2004 r. o podatku od towarów i usług (tekst jedn. Dz.U. z 2016, poz. 710 ze zm., dalej: ustawa o podatku od towarów i usług).

$58 \quad$ K. Żurek, Status prawnopodatkowy wspólników..., s. 26.

59 Wyrok WSA w Gorzowie Wielkopolskim z dnia 11 grudnia 2013 r., I SA/Go 422/13, CBOSA.
} 
i usług, jak przypadku tradycyjnej spółki cywilnej ${ }^{60}$, to zaś w sposób istotny wpływa na odpowiedzialność wspólnika cichego za zobowiązania podatkowe z tytułu podatku od towarów i usług.

\section{Uwagi de lege lata i de lege ferenda}

Brak regulacji normatywnej spółki cichej - wobec jest powszechności w stosunkach gospodarczych - należy ocenić negatywnie. Wniosek ten szczególnie uzasadniony jest niepewnością podatnika co do rozstrzygnięć organu podatkowego czy sądu w jego sprawie związanej z zawartą i wykonywaną przez niego umową spółki cichej. W zależności bowiem od ujęcia charakteru prawnego umowy spółki cichej możliwe jest dowolne kształtowanie sytuacji prawnopodatkowej wspólnika tej spółki, niekiedy wręcz z naruszeniem zakazu dokonywania rozszerzającej wykładni prawa podatkowego na niekorzyść podatnika.

Przedstawiona powyżej analiza możliwych skutków zawarcia i wykonywania umowy spółki cichej na gruncie ogólnego prawa podatkowego, podatku dochodowego od osób fizycznych oraz od osób prawnych, podatku od czynności cywilnoprawnych, podatku od spadków i darowizn oraz podatku od towarów i usług wskazuje jednoznacznie, iż de facto ewentualne ustalenie przez organ podatkowy powstania ewentualnego zobowiązania podatkowego czy określenie odpowiedzialności za zobowiązania podatkowego przedsiębiorstwa prowadzonego w ramach spółki cichej uzależnione jest od przyjęcia przez organ orzekający jednej z dwóch koncepcji spółki cichej - jako umowy czysto zobowiązującej bądź też jako szczególnej formy spółki cywilnej. Brak jednolitego poglądu w tej kwestii powoduje niebezpieczeństwo na gruncie prawa podatkowego, w szczególności dla wspólnika cichego, gdyż w przypadku przyjęcia przez niego, że umowa spółki cichej jest umowa jedynie czysto obligacyjną ewentualna odmienna kwalifikacja organu podatkowego wiązała-

60 Tak m.in. NSA w wyroku z dnia 14 września 2010 r., I FSK 1443/09, CBOSA, który wskazał, że na gruncie przepisów o podatku VAT spółce cywilnej jako organizacji wspólników (a nie wspólnikom) przyznano podmiotowość prawnopodatkową. 
by się dla niego z dodatkowymi, nieprzewidywanymi w chwili zawierania umowy, skutkami finansowymi.

Zalecane zatem byłoby stworzenie regulacji ustawowej dotyczącej spółki cichej. Taka regulacja, obejmującą essentialia negotii spółki cichej, przesądziłaby o właściwej kwalifikacji prawnej tej spółki i potwierdziłaby wyrażany w doktrynie pogląd o odrębności i samodzielności tej konstrukcji wobec innych stosunków prawnych znanych w polskim prawie. Prawne uregulowanie kwestii spółki cichej pozwoliłoby ustawodawcy do ewentualnego odniesienia się wprost w ustawach podatkowych do tej konstrukcji. Tym samym możliwe byłoby jednoznaczne stwierdzenie, czy ustawodawca chciał objąć zakresem określonego podatku również aspekty związane ze spółką cichą, czy też nie. Zaznaczyć przy tym należy, iż dla kwestii realizacji postulatu pewności nie ma znaczenia, w jakim akcie prawnym zamieszczona zostanie regulacja dotycząca spółki cichej oraz jaki charakter spółki cichej zostanie przez ustawodawcę nadany (czy to jako umowy zobowiązaniowej, szczególnej formy spółki cywilnej czy też może spółki prawa handlowego), a istotne jest stworzenie regulacji pozwalającej na jednoznaczną kwalifikację spółki cichej na gruncie prawa podatkowego.

\section{Bibliografia:}

Jacyszyn J., Spółka cicha jako forma prowadzenia działalności gospodarczej w Polsce, „Rejent” 1994 r., nr 7-8, s. 89-117.

Jędrejek G., Spółka cicha, Wolters Kluwer Polska, Warszawa 2008.

Jędrzejewska A., „Cywilna” spółka o charakterze wewnętrznym a „handlowa” spółka cicha, „, Przegląd Prawa Handlowego”, 1995 nr 5, s. 13-19.

Jędrzejewska A., Spółka cicha na tle innych podobnych form kapitałowego współdziałania osób, „Przegląd Prawa Handlowego” 1995, nr 4, s. 8-14.

Jędrzejewska A., Z problematyki nietypowej spółki cichej, „Przegląd Prawa Handlowego" 1995 r., nr 3, s. 1-5.

Koch A., Spółka cicha w świetle przepisów kodeksu cywilnego, „Przegląd Prawa Handlowego" 1995, nr 7, s. 1-7.

Koronkiewcz A., Spółka cicha jako umowa sui generis, „Rejent” 2007, nr 1 (189), s. 127-144. 
Niestrzębski D., Umowa spółki cichej a opłata skarbowa, „Przegląd Podatkowy” 1997, nr 5, s. 13-14.

Przekopiak J., Opodatkowanie przychodów wspólnika cichego uzyskanych z uczestnictwa w spółce cichej, „Prawo Spółek” 1997, nr 4, s. 57-59.

Żurek K., Spółka cicha. Charakter prawy. Funkcje i zalety. Wzory pism, Zakamycze, Kraków 1999.

Żurek K., Status prawnopodatkowy wspólników spółki cichej, „Prawo Spółek” 1999, nr 11, s. 23-27. 